\title{
EXTERNAL EAR ANTHROPOSCOPY IN FEMALE STUDENTS OF THE UNIVERSITY OF SZCZECIN
}

\begin{abstract}
Background: Personal identification based on anthroposcopic characteristics, including the features of the external ear, has recently become highly desirable. This growing interest results from increasing public safety requirements, as well as the ever more numerous practical applications of somatometry and somatoscopy. Especially when there is no biological material necessary for DNA testing, and where instead there are photographs or surveillance footage, being able to identify a person based on anthroposcopic features is an attractive alternative.

Aim: The aim of this paper is to investigate the structural diversity of the external ear among the female students of the University of Szczecin and to demonstrate the viability of external ear biometrics in personal identification.

Materials and methods: a group of young women $n=65$, students of the University of Szczecin, aged $21-29$ years $(\bar{x}=23.7)$. Structural differences were assessed based on photographs of the left and right ear. Individual characteristics describing the ear were classified according to the adopted criteria. The prevalence of each external ear feature included in the somatoscopic assessment was described as a percentage.
\end{abstract}

\footnotetext{
* University of Szczecin, Department of Vertebrate Zoology and Anthropology, Wąska 13, 71-415 Szczecin, Poland, e-mail: rebae@univ.szczecin.pl
} 
Results: The majority of students included in the study had a moderately or prominently curled helix and a long crus of helix. The antihelix with its superior crus were often found to be prominent, as was the antitragus. The tragus was predominantly single and the intertragic notch - moderate. The lobe surface was observed to be rather underdeveloped; attached lobes were found in half of the participants, whereas the remainder had detached lobes.

Conclusion: Ear somatoscopy may be an auxiliary method in personal identification when video recordings or photographs are available.

Keywords: anthropology, somatoscopy, personal identification, external ear

\section{Introduction}

Among the features observable in human beings, the face is regarded as the most unique and characteristic. The process of identifying a person who is known to us relies primarily on visual stimuli. Automated personal identification based on individual characteristics has recently become highly desirable. The growing interest in personal identification techniques is the result of increasing public safety requirements. The advances in information technology have created practical applications for the use of anthroposcopic information. For many years, researchers have been working on creating automated personal identification systems based on individual morphological characteristics captured by photography or filming. Real-time analysis has the advantages of being non-invasive and allowing for perfectly natural behaviours on the part of the studied person. As a result, it may be used in a wide range of situations and circumstances, for instance in forensics, such as criminal investigations and missing person searches, during disasters, or in high-security systems - to control access (Gajlikowska 2009).

In creating databases of anthroposcopic, anthropometric and/or physiological features, biometric methods are helpful. Biometrics may be divided into two broad categories: physical and behavioural. Physical biometrics include: shape of the hand and nails, eye colour (iris), hair colour and type, fingerprints, footprints, cheiloscopy (lip traces), ear shape (auricle), skin colour, face geometry and many others (Kiełbus et al. 2014). In turn, behavioural features include: gait, signature (handwriting), voice. 
Ear biometrics have been elaborated into a scientific method widely used in personal identification. One of the first ear biometric systems was developed by Alfred Iannarelli in 1949 and named after him as the Iannarelli System (Kaushal et al. 2011). In a series of experiments, he managed to prove that ear structures are unique, not only in unrelated individuals, but also in twins. His analysis involved a comparison of 12 ear measurements between reference points oriented in relation to a central point (Choraś 2004). The measurements were taken using aligned and size-standardised photographs of the ear. This method, however, has not found an application in contemporary computer systems used for personal identification, due to the difficulty inherent in automated determination of the central point, to which all measurements were relative (Kukharev et al. 2003).

Another method for examining ear images relies on passive biometric systems. This method can be used to identify individuals in surveillance footage, e.g. on public transport, in and around supermarkets, airports, large sports events, public areas. A passive system does require the cooperation of the subject. The analysed material is a video recording or photographs. The advantage of ear biometrics compared to face biometrics is that the former remain relatively stable over time, which means that reference images do not need to be updated very often. This constitutes a very strong argument for using the ear in personal identification analyses (Choraś 2004). To describe ear shape, Mark Burge and Wilhelm Burger (1996) created a system based on an adjacency graph built from the Voronoi diagram describing geometrical curve segments (graph matching method) (Choraś 2004). The main problem with ear biometrics is posed by hair and headgear, which cover the outer ear and contribute to numerous errors (Pacut et al. 2003). If the ear is obscured only to a small extent, it can be recognised through image segmentation, using various colours and textures. This problem was solved by using a thermogram, that is the thermal image (Burge et al. 1996).

With the development of new technologies, even better ear identification has become possible by comparing information from 2D and 3D images (Bowyer et al. 2006). A three-dimensional image is created using an ICP algorithm (Iterative Closest Point), which makes it possible to separate the ear from the overall image (Kong et al. 2005; Yan et al. 2006). ICP is widely used to reconstruct a three-dimensional environment from a sequence of $3 \mathrm{D}$ environmental scans (Fabry et al. 2010).

The ear has been employed in anthropological studies to determine paternity. However, as it turned out, it was impossible to prove or disprove paternity with 
$100 \%$ confidence using this method. It only allowed for determining the degree of probability (Krzemiński 2008). At present, genetic testing is used to determine consanguinity, as it carries a lower risk of error, is quicker to perform and requires less effort.

The ear may be regarded as a separate, unique structure. The ear is part of the head, but compared to the face it is slower to age and is not affected by emotional or mental state (Khursheed et al. 2014). Thanks to modern computer graphics, the ear is an attractive biometric identifier for research purposes. The ear is a viable biometric because it is unique to an individual, does not change much over time and is easy to extract (visible in surveillance). Ear anthroposcopy may be used to identify the victims of mass disasters, where the face has been seriously disfigured, in the case of extensive burns, bites (Kaushal et al. 2011; Dhanda et al. 2011).

The aim of this paper is to investigate the structural diversity of the external ear among the female students of the University of Szczecin and to demonstrate the viability of external ear biometrics in personal identification.

\section{Research material and methods}

The study sample was a group of young women $\mathrm{n}=65$, students of the University of Szczecin, aged 21-29 years $(\bar{x}=23.7)$. The research was conducted in AprilMay 2014.

Structural differences were assessed based on photographs of both ears. Individual characteristics describing the ear were classified according to the criteria adopted by Zofia Szczotkowa (1985). The method was non-invasive, based on a subjective assessment of ear features according to the adopted criteria. The ears were photographed with the consent of the participating students.

The outer ear (also known as the auricle or pinna) is mostly made of a cartilage complex which creates its complicated relief (Fig. 1), except for the earlobe [ptatek], which is made primarily of connective and fatty tissue. The shape of the outer ear is largely determined by its rim - the helix [obrabek], which may present with a varying degree of folding. It starts with the crus of helix [odnoga obrabka] and ends at the upper edge of the earlobe. Parallel and in front of the helix, runs the anthelix [grobelka] whose shape affects the depth and size of the concha [muszla matzowiny]. Running upwards, it branches out into two crura: superior and inferior [górna/dolna odnoga grobelki]. The origin of the antihelix 
borders on the antitragus [przeciwskrawek], from which it is separated by the posterior auricular groove. The antitragus may be well visible, or barely noticeable. The tragus [skrawek] protects the ear canal anteriorly and is separated from the antitragus by the intertragic notch [wcięcie międzyskrawkowe] (Kaushal et al. 2011).

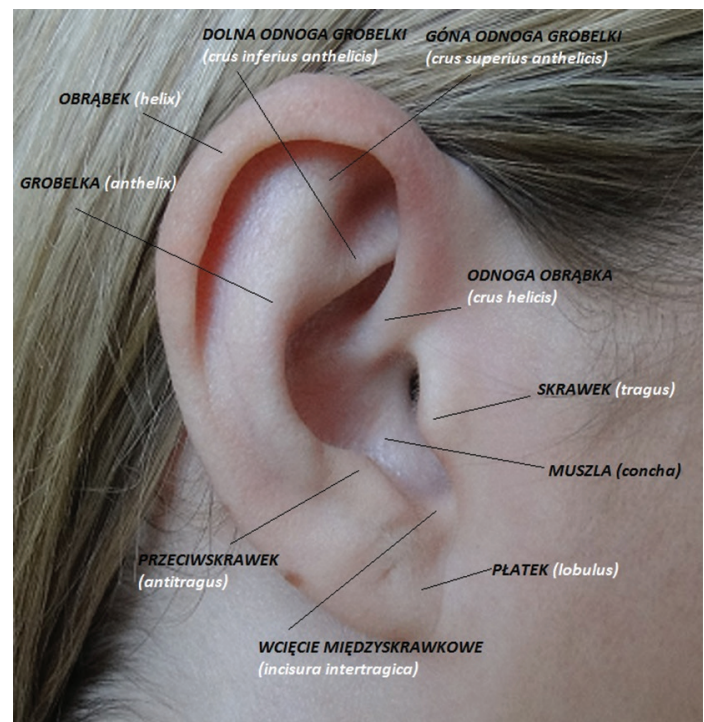

Figure 1. Anatomical parts of the external ear (photo by Natalia Nitecka)

Variation in selected ear features (categorisation):

Feature: Folding of the upper edge of the helix (superior helix)

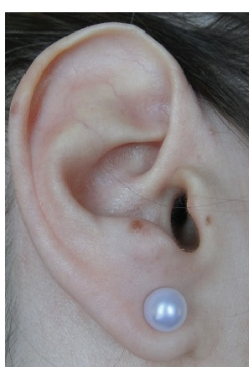

Figure 2. Underfolded

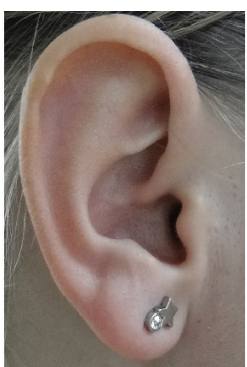

Figure 3. Underdeveloped

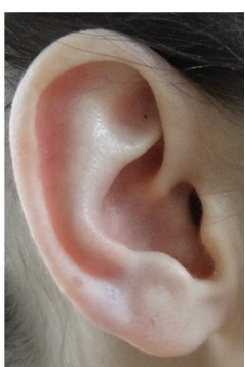

Figure 4. Moderate

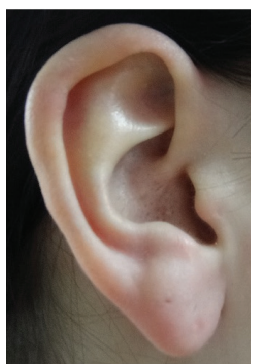

Figure 5. Prominent

Feature: Folding of the lower edge of the helix (descending helix). 


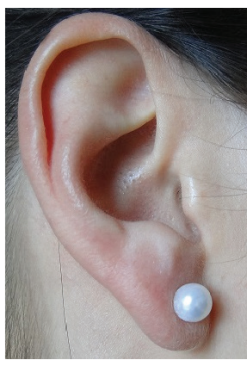

Figure 6.

Underfolded

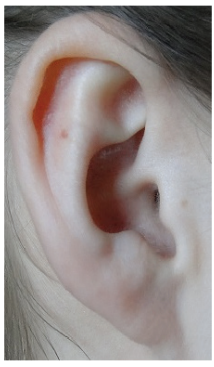

Figure 7.

Underdeveloped

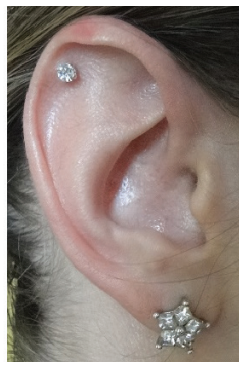

Figure 8.

Moderate

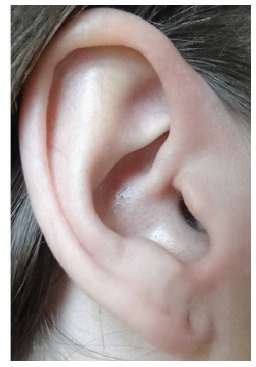

Figure 9.

Prominent

Feature: Formation of the crus of helix Feature: Shape of the tragus

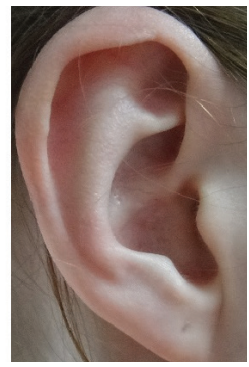

Figure 10. Short

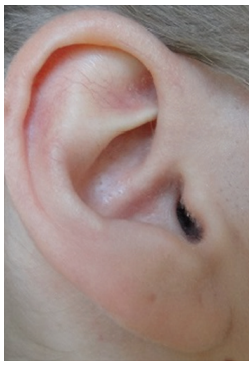

Figure 11. Long

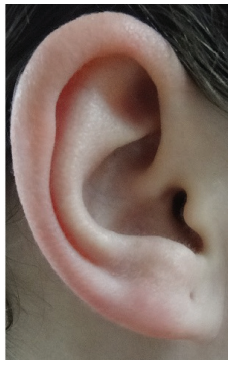

Figure 12.

Single eminence

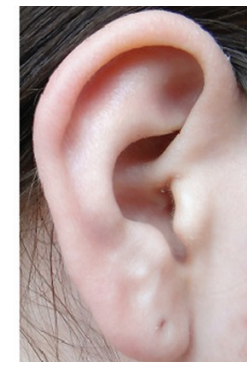

Figure 13. Bifid (split)

Feature: Formation of the antihelix

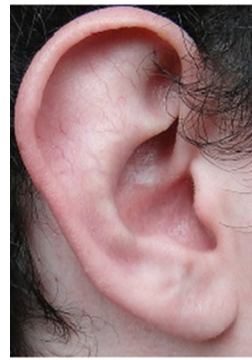

Figure 14. Underdeveloped

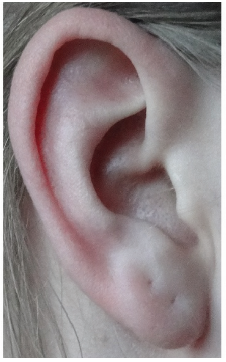

Figure 15.

Moderate

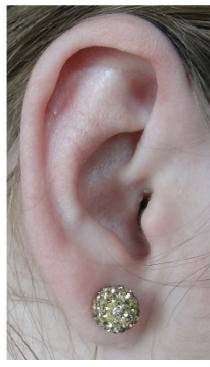

Figure 16. Prominent 
Feature: Formation of the superior crus of antihelix.

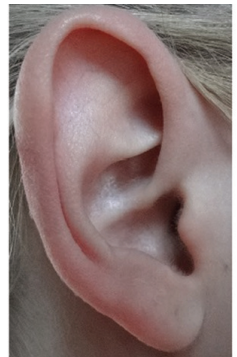

Figure 17. Underdeveloped

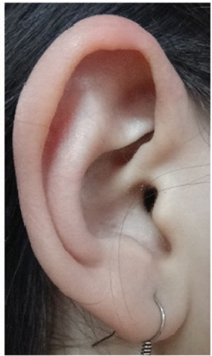

Figure 18.

Moderate

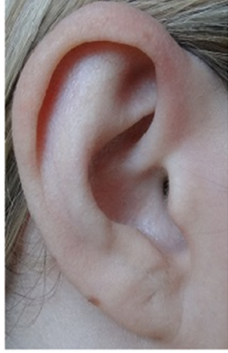

Figure 19.

Prominent

Feature: Prominence of the antitragus.

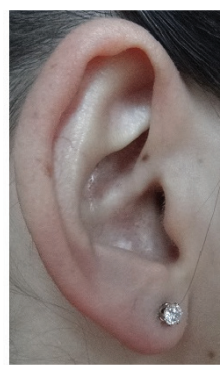

Figure 20. Underdeveloped

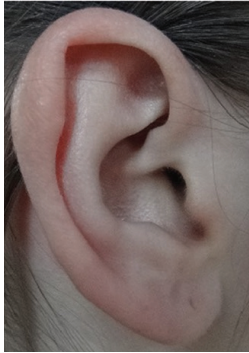

Figure 21. Moderate

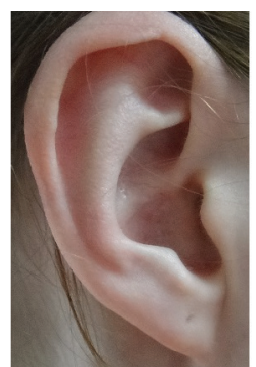

Figure 22.

Prominent

Feature: Anterior profile of the earlobe

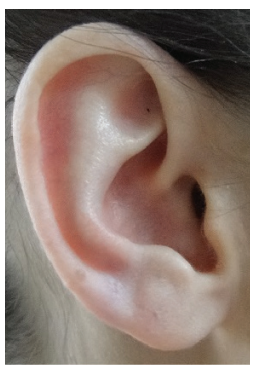

Figure 23. Convex

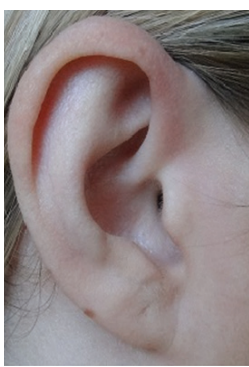

Figure 24. Underdeveloped

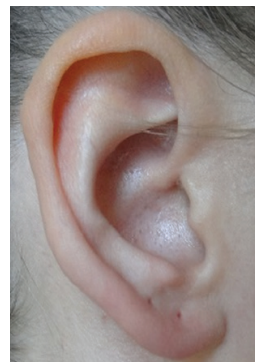

Figure 25 .

Concave 
Feature: Attachment of the earlobe

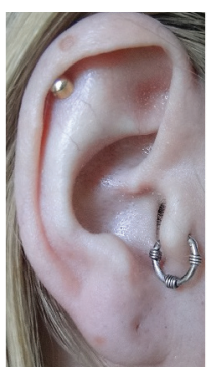

Figure 26.

Attached

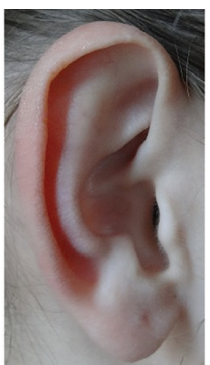

Figure 27.

Detached

Feature: Width of the intertragic notch

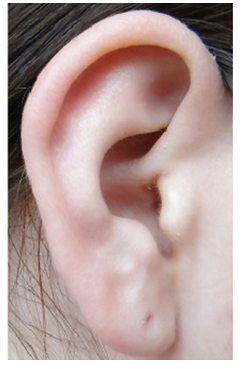

Figure 28. Narrow

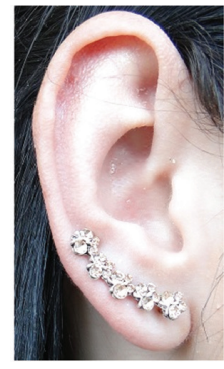

Figure 29. Moderate

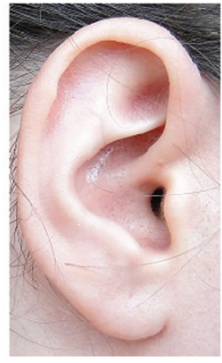

Figure 30. Wide

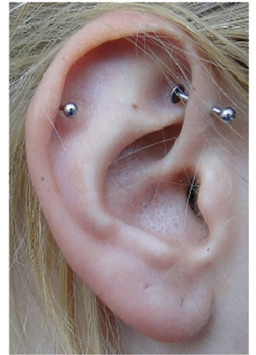

Figure 31. Very wide

\section{Results}

\section{Analysis of ear anatomy}

Ear biometrics were analysed based on the adopted classification of somatoscopic features (Szczotkowa 1985).

The superior helix (Fig. 2-5) of the right and left ear was found to be prominently curled in $41.5 \%(\mathrm{n}=27)$ of the participating women. In turn, $41.5 \%$ $(n=27)$ had a moderately curled superior helix in the left ear, and $43.1 \%(n=28)$ in the right ear. Weak folding or an underfolded superior helix in the right ear was characteristic of $15.5 \%(\mathrm{n}=10)$ of the participating women, and of $16.9 \%$ $(\mathrm{n}=11)$ in the case of the left ear. 
Prominent folding of the descending helix (Fig. 6-9) was observed in $24.6 \%$ $(n=16)$ of the right ears and in $23.1 \%(n=15)$ of the left ears included in the study. A moderate degree of folding in the descending helix was found in $30.8 \%$ $(n=20)$ of the right ears and in $32.3 \%(n=21)$ of the left ears. Lastly, underdeveloped folding or underfolding of the descending helix in both ears was characteristic of $44.6 \%(n=29)$ of the participating women. The percentage differences in the prevalence of this feature between the right and left ear were not statistically significant.

A clear majority of the participating women presented with a long crus of helix (right ear: $69.2 \% \mathrm{n}=45$; left ear: $66.2 \% \mathrm{n}=43$ ) (Fig. 10-11). In the remaining number of women, the crus of helix was short.

Formation of the tragus (Fig. 12-13) had the most unilateral distribution out of all the features included in the present analysis. In the vast majority of the participating women, a single tragal eminence was observed; right ear $83.1 \%(\mathrm{n}=54)$ and left ear $81.5 \%(n=53)$. A bifid tragus was found in $16.9 \%(n=11)$ of women in the right auricle and in $18.5 \%(\mathrm{n}=12)$ for the left auricle.

Among all the ear structures subject to analysis, the formation of the antihelix was clearly one of those unevenly distributed among the adopted categories (Fig. 14-16). In $75.4 \%(n=49)$ of the right ears and in $80.0 \%(n=52)$ of the left ears, prominent folding of the antihelix was observed. The remainder had moderately or weakly folded antihelices.

The formation of the superior crus of antihelix was another feature assessed in the participating students (Fig. 17-19). For both right and left ears, a prominently defined superior crus of antihelix was observed in 53.8\% $(\mathrm{n}=35)$. Moderate folding of the superior crus of antihelix: right ear $41.5 \%(n=27)$ and left ear $40 \%$ $(\mathrm{n}=26)$. The remaining women had an underdeveloped superior crus of antihelix.

The degree of prominence of the antitragus was relatively evenly distributed in both ears across the study sample (Fig. 20-22). A prominent antitragus was characteristic of $49.2 \%(n=32)$ of the women for the right ear and $52.3 \%(n=34)$ for the left. In turn, a moderate prominence was found in $40.0 \%(n=26)$ of the participants in the right ear and $36.9 \%(\mathrm{n}=24)$ in the left. The remaining $10.8 \%$ $(n=7)$ of students had an underdeveloped antitragus in both ears at the same time.

Another feature covered by the present analysis was the surface of the earlobe (Fig. 23-25). A convex earlobe profile in the right ear was found in 16.9\% $(\mathrm{n}=11)$ of the participants and in the left ear in $15.4 \%(\mathrm{n}=10)$. An underdeveloped earlobe profile in the right ear was observed in $63.1 \%(n=41)$ and $69.2 \%$ 
$(n=45)$ in the left ear. The concave earlobe profile was present in $20.0 \%(n=13)$ in the right ear and $15.4 \%(\mathrm{n}=10)$ in the left.

The type of earlobe attachment (Fig. 26-27) was found to be the same in both ears. Attached and detached earlobes were nearly equally distributed, respectively: $50.8 \%(\mathrm{n}=33)$ and $49.2 \%(\mathrm{n}=32)$.

With regard to the characteristic described as the width of the intertragic notch (Fig. 28-31), a narrow notch as well as a wide notch was observed in $21.5 \%$ $(n=14)$ of the participants, a moderate notch was found in $55.4 \%(n=36)$ of the participants, and one case (1.5\%) presented with a very wide intertragic notch.

The ear structures covered by the present analysis do not exhaust all the options of ear somatoscopy, as only the most often used features were selected for the purpose of this study.

\section{Discussion}

The external ear is different and distinct in each individual. Postnatally, ear structures are subject to little change. Ear growth can be observed in the elderly. It is due to the changes in cartilage, the main type of tissue that the ear is made of. Conditions such as acromegaly, associated with excessive secretion of the growth hormone, also cause an overgrowth of soft tissues (Aydin et al. 2012). Ear structures may also be altered by all kinds of human intervention, which may provide some information on the cultural background and fashion trends. The photographs used in this paper show various ear ornaments popular among the contemporary Polish youth. They point to a cultural change which involves adopting body ornamentation models from exotic regions of the world. Piercing other parts of the ear than the lobe (lobulus auriculae) used to be very uncommon in Poland in the past.

Analysis of the material reveals the morphological diversity of ear structures among unrelated female students of the University of Szczecin. The students included in the study most often had a moderately or prominently folded helix and a long crus of helix. The antihelix with its superior crus were often found to be prominent, as was the antitragus. The tragus was predominantly single and the intertragic notch moderate. The lobe surface was observed to be rather underdeveloped; attached lobes were found in half of the participants, whereas the other half had detached lobes. 
Comparing the present findings with Szczotkowa's research, one can confirm her hypothesis that in the Polish population, especially in women, the least common anatomical variations include the underfolded helix, underdeveloped antihelix and convex earlobe (Szczotkowa 1985). Szczotkowa's material was collected more than 30 years ago, but the morphological characteristics of the external ear in the Polish population are similar today.

It is worth noting that the assessment of ear structures is a subjective method. Analysis of the complex ear anatomy is useful in personal identification using modern computer-aided techniques. Public surveillance systems are now equipped with advanced digital asset management software which can catalogue photographs and recognise similarities automatically. These days, it is not uncommon for cameras (compact cameras, camera phones, video recorders etc.) to feature - as manufacturers' advertisements claim - face recognition, i.e. identification based on the unique biometric features of the user. The same mechanism may be used in identification systems based on the ear image. Biometric techniques using the face or another visible part of the body can be easily integrated with the current surveillance systems and their databases. In this way, new applications for contemporary biometry may be developed. In stationary solutions, where the information is stored to be analysed later, the image becomes a "security pass" which controls an individual's activity, for instance: registers employees' arrival/departure (at the office, secure area), monitors working hours, grants access to classified information. In turn, visitor count in public places or alerting the presence of certain individuals in areas under surveillance are examples of dynamic situations, in which the use of biometry, including somatoscopy, is very helpful. Real-time interactive personal identification, where the results are to be used immediately, can be applied to: trigger alerts upon detecting wanted/missing people, open doors automatically to registered users, trigger an alarm upon detecting an unregistered or wanted person on the premises under surveillance, operate the "intelligent door phone", identify the computer user, restrict access to chosen television channels (upon recognising a child).

Biometry has a wide range of applications because - with the developments in information technology - more and more information can be obtained from the human body. Identification based on documents is not enough today to be confident as to a given person's identity. The analysis of somatoscopic features, such as fingerprints, eye colour, ear morphology and others, lends itself to establishing a person's identity in a non-invasive manner. That is why it is necessary to under- 
take steps aimed at creating databases of the citizens' somatoscopic characteristics, so that in case of large-scale emergencies, such as transportation accidents, terrorist attacks, natural disasters etc., the available morphological data on the human body are at the ready.

\section{Conclusions}

The somatoscopic analysis of ear features in the female students of the University of Szczecin points to the following conclusions:

- The image of the external ear constitutes valuable personal information.

- The most prevalent external ear features observed in the participating students of the University of Szczecin include a moderately or prominently curled helix, prominently formed antihelix and its superior crus, prominent antitragus, a single eminence of the tragus, moderate intertragic notch, underdeveloped anterior profile of the earlobe, which may be attached or detached.

- The least common features observed in the women included in the present study include an underfolded helix, an underdeveloped antihelix and a convex profile of the earlobe.

- The analysed features of the external ear are not necessarily symmetrical, i.e. developed to the same degree in both ears.

- Unconventional ear ornamentation (adopted from other cultures) in contemporary young Polish women is becoming more and more popular.

Analysis of the external ear and other biometric data in combination with the available diagnostic methods improves the chances for accurate personal identification. Recognising the registered morphological features in a subject will make it possible to prove or disprove them as the victim/perpetrator involved in an incident. Consequently, it will help to build public confidence, apprehend perpetrators of criminal acts and enhance public safety.

\section{References}

Aydin K., Ozturk B., Turkyilmaz M.D., Dagdelen S., Ozgen B., Unal F, Erbas T. 2012. Functional and structural evaluation of hearing in acromegaly. Clinical endocrino$\log y, 76$ (3): 415-419. 
Bowyer K.W., Chang K., Flynn P. 2006. A survey of approaches and challenges in 3D and multi-modal 3D + 2D face recognition. Computer Vision and Image Understanding, 101 (1): 1-15.

Burge M., Burger W. 1996. Ear Biometrics. Johannes Kepler University Linz, Austria.

Choraś M. 2004. Biometrics Identyfication Methods Based on Human Ear Images. Techniki Komputerowe. Biuletyn Informacyjny, 1: 59-69.

Dhanda V., Badhan J.S., Garg R.K. 2011. Studies on the development of latent ear prints and their significance in personal identification. Problems of Forensic Sciences, LXXXVIII: 285-295.

Fabry T., Smeets D., Vandermeulen D. 2010. Surface representations for 3D face recognition. In: Face Recognition. M. Oravec (ed.). InTech, www.intechopen.com/books/ face-recognition/surface-representations-for-3d-face-recognition.

Gajlikowska B. 2009. Problem outline of automatic compensation of changes influence by flow of time in face recognition systems. Prace Instytutu Elektrotechniki, 243: 27-42.

Kaushal N., Kaushal P. 2011. Human Earprints: A Review, Journal of Biometrics and Biostatistics, 2: 5, http://dx.doi.org/10.4172/2155-6180.1000129.

Khursheed F., Mir A.H. 2014. AR Model Based Human Identification using Ear Biometrics, International Journal of Signal Processing, Image Processing and Pattern Recognition, 7 (3): 347-360.

Kiełbus A., Furyk K. 2014. Nowe technologie i zastosowania w biometrii-analiza rynku. Instytut Technologii Maszyn i Automatyzacji Produkcji Politechniki Krakowskiej, Kraków.

Kong S.G., Heo J., Abidi B.R., Paik J., Abidi A.M. 2005. Recent advances in visual and infrared face recognition - a review. Computer Vision and Image Understanding, 97 (1): 103-135.

Krzemiński Z. 2008. Alimenty i ojcostwo: komentarz. Wolters Kluwer Polska, Warszawa.

Kukharev G., Kuźmiński A. 2003. Techniki biometryczne. Czesść 1. Metody rozpoznawania twarzy. Pracownia Poligraficzna WI PS, Szczecin.

Pacut A., Czajka A. 2003. Twój PIN to TY. Biometryczne metody weryfikacji tożsamości, część II. Biuletyn NASK, marzec-kwiecień-maj: 18-24.

Szczotkowa Z. 1985. Antropologia $w$ dochodzeniu ojcostwa. PWN, Warszawa-Wrocław.

Yan P., Bowyer K.W. 2006. An Automatic 3D Ear Recognition System. Department of Computer Science and Engineering University of Notre Dame, Notre Dame. 


\section{ANTROPOSKOPIA MAŁŻOWINY USZNEJ STUDENTEK UNIWERSYTETU SZCZECIŃSKIEGO}

\section{Streszczenie}

Wprowadzenie: Identyfikacja osób na podstawie cech antroposkopijnych, w tym budowy małżowiny usznej, jest obecnie wysoko pożądana. Wzrost zainteresowania wynika z rosnących wymagań odnośnie bezpieczeństwa społecznego, jak i możliwości wykorzystania somatometrii i somatoskopii w praktyce. Zwłaszcza kiedy brak materiału biologicznego niezbędnego do badań DNA, a istnieją fotografie lub nagrania z monitoringu, możliwość utożsamienia na podstawie cech antroposkopijnych jest korzystną alternatywą.

Cel: Zbadanie zróżnicowania budowy małżowiny usznej wśród studentek Uniwersytetu Szczecińskiego oraz wykazanie atrakcyjności badawczej małżowiny usznej w identyfikacji osobniczej.

Material i metoda: Grupa młodych kobiet $n=65$, studentek Uniwersytetu Szczecińskiego w wieku 21-29 lat ( $\bar{x}=23,7)$. Ocenę zróżnicowania budowy małżowiny usznej dokonano na podstawie fotografii prawego i lewego ucha. Poszczególne cechy opisujące małżowinę uszną poddano przyjętej kategoryzacji. Każdą ocenianą somatoskopijnie cechę małżowiny usznej ujęto w zestawieniu procentowym.

Wyniki: Badane studentki najczęściej posiadały miernie bądź silnie zagięty obrąbek i długą jego odnogę. Często występowało silne wykształcenie grobelki wraz z jej górną odnogą i mocne ukształtowanie ,górnego guzka” przeciwskrawka. Skrawek był jednoguzkowy, natomiast wcięcie międzyskrawkowe kształtowało się miernie. Płatek wykazywał słabą rzeźbę i był u połowy badanych całkowicie przyrośnięty, a u pozostałej części kobiet częściowo przyrośnięty.

Wnioski: Somatoskopia małżowiny usznej może być metodą pomocniczą w identyfikacji osobniczej, wówczas kiedy dysponujemy nagraniami bądź fotografiami.

Słowa kluczowe: antropologia, somatoskopia, identyfikacja osobnicza, małżowina uszna

Cite this article as: Rębacz-Maron E., Nitecka N. 2015. External ear anthroposcopy in female students of the University of Szczecin. Acta Biologica, 22: 153-166. 